\title{
Methane formation and consumption by sediments in a cross-channel profile of a small river impoundment
}

\author{
Adam BEDNAŘÍK, ${ }^{1 *}$ Martin BLASER, ${ }^{2}$ Martin RULÍK${ }^{1}$ \\ ${ }^{1}$ Department of Ecology and Environmental Sciences, Laboratory of Aquatic Microbial Ecology, Palacky University of Olomouc, \\ Czech Republic; ${ }^{2}$ Department of Biogeochemistry, Max Planck Institute for Terrestrial Microbiology, Marburg, Germany
}

\begin{abstract}
Rivers are a natural source of methane $\left(\mathrm{CH}_{4}\right)$ into the atmosphere and may contribute significantly to total $\mathrm{CH}_{4}$ emissions. Even though the details of sources of $\mathrm{CH}_{4}$ in rivers are not fully understood, weirs have been recognized as a hotspot of $\mathrm{CH}_{4}$ emissions. In this study, we investigated $\mathrm{CH}_{4}$ production and consumption in air-exposed river sediments along a cross-channel transect located upstream of a weir. Stable carbon isotopes were used for determination of individual methanogenic pathways. In order to understand the relationship between physicochemical and biological processes, additional parameters such as organic matter, grain median size, and carbon and nitrogen content were characterized as well. Generally, samples from the surface sediment layer $(0-10 \mathrm{~cm})$ had higher $\mathrm{CH}_{4}$ production than sediments from the deeper layer $(10-20 \mathrm{~cm})$ during the incubation experiments. Sediments near the bank zones and in the mid-channel were characterized by the highest organic carbon content $(6.9 \%)$ as well the highest methanogenic activity $\left(2.5 \mathrm{mmol} \mathrm{g}^{-1} \mathrm{DW} \mathrm{d}^{-1}\right)$. The $\mathrm{CH}_{4}$ production was predominated by $\mathrm{H}_{2} / \mathrm{CO}_{2}$ dependent methanogenesis in the surface sediment layer $(0-10 \mathrm{~cm})$, while the proportion of acetoclastic and hydrogenotrophic methanogenesis in the deeper sediment layer $(10-20 \mathrm{~cm})$ was balanced. The $\mathrm{CH}_{4}$ oxidation potential of sediments showed the same spatial pattern as observed for the $\mathrm{CH}_{4}$ production. Our results showed high spatial variability of sediment $\mathrm{CH}_{4}$ production and oxidation in the cross-channel profile upstream of the weir, whereas the highest $\mathrm{CH}_{4}$ dynamics were observed in the littoral zones. This variability was closely linked with the carbon and nitrogen content in the sediment samples.
\end{abstract}

\section{INTRODUCTION}

Inland freshwater habitats including streams and rivers have been recognized to be an important source of methane $\left(\mathrm{CH}_{4}\right)$ into the atmosphere (Bastviken et al., 2011; IPCC, 2013; Deemer et al., 2016). Recent studies show that impounded river zones are $\mathrm{CH}_{4}$ emission "hotspots", significantly enhancing our estimations of $\mathrm{CH}_{4}$ emissions from rivers (Maeck et al.,; 2013, Wilkinson et al., 2015). River reaches immediately upstream of impoundments are characterized by significantly changed physicochemical parameters of the water, creating transitions between lentic and lotic water ecosystems (Gao et al., 2013). For example, Ogbeibu and Oribhabor (2002) found significantly lower

Corresponding author: adambednarik01@gmail.com

Key words: Methane; river impoundment; methane production; river sediment; methanogenic pathways.

Edited by: Franco Tassi, University of Florence, Italy

Received: 16 February 2019.

Accepted: 23 April 2019.

This work is licensed under a Creative Commons Attribution NonCommercial 4.0 License (CC BY-NC 4.0).

${ }^{\circ}$ Copyright: the Author(s), 2019

Licensee PAGEPress, Italy

J. Limnol., 2019; 78(2): 233-242

DOI: $10.4081 /$ jlimnol.2019.1898 water transparency, current velocity and concentration of dissolved oxygen in reservoirs compared to rivers. The $\mathrm{CH}_{4}$ emitted from these sites is mostly derived from sediment $\mathrm{CH}_{4}$ production resulting from an increased sedimentation rate and poor vertical mixing, causing dissolved oxygen decline and anaerobic sedimentary activity upstream of the impoundments (Barth et al., 2003; Maeck et al., 2013). However, spatial variability of $\mathrm{CH}_{4}$ production and oxidation in these environments is poorly understood, as is the contribution of individual methanogenic pathways to the total $\mathrm{CH}_{4}$ production.

In principal, $\mathrm{CH}_{4}$ is produced during anaerobic degradation of organic matter in freshwater sediments (Zinder, 1993). Anaerobic degradation of carbohydrates results in two dominant intermediates $\left(\mathrm{H}_{2} / \mathrm{CO}_{2}\right.$ and acetate), which are further processed by two different metabolic pathways of $\mathrm{CH}_{4}$ production hydrogenotrophic methanogenesis (using $\mathrm{H}_{2} / \mathrm{CO}_{2}$ ) and acetoclastic methanogenesis (using acetate). Quantification of the relative contribution of both sources can be made by using stable carbon isotopic signals, due to different ${ }^{13} \mathrm{C} /{ }^{12} \mathrm{C}$ fractionation during conversion of $\mathrm{CO}_{2}$ and acetate methyl to $\mathrm{CH}_{4}$ (Conrad, 2005). Contribution of these methanogenic pathways to total $\mathrm{CH}_{4}$ production differs in various freshwater habitats. A fraction of hydrogenotrophic methanogenesis is usually prevailing in lake sediments (Conrad et al., 2011), while acetoclastic methanogenesis dominates in rice paddy soils (Scavino et al., 2013) and peatlands (Galand et al., 2010).

Studies dealing with the spatial variability of $\mathrm{CH}_{4}$ production in the sediments of lakes, reservoirs and rivers 
emphasize littoral zones as main sites of methanogenic activity (Bastviken et al., 2008; Musenze et al., 2014; Yang et al., 2014). Murase et al. (2005) found that littoral sediments of lakes can reach substantially higher $\mathrm{CH}_{4}$ production than profundal sediments, and further served as a source of dissolved $\mathrm{CH}_{4}$ in lakes together with tributary rivers. Increased $\mathrm{CH}_{4}$ release from littoral sediments is likely given by (1) greater availability of labile organic matter from the aquatic vegetation, (2) wave turbulence and bottom shear stress, which enhance sediment flux rates, and (3) higher temperatures in summer months, which in turn support higher $\mathrm{CH}_{4}$ production rates (Bussmann, 2005; Hofmann et al., 2010).

Similarly, there is an evident spatial distribution of surface water $\mathrm{CH}_{4}$ concentration in large rivers. Richey et al. (1988) and Anthony et al. (2012) have shown $\mathrm{CH}_{4}$ cross-channel gradients with increased $\mathrm{CH}_{4}$ concentrations observed nearby the banks compared to mid-channel, while Sawakuchi et al. (2014) observed a different trend in the Amazon and Pará rivers, with high mid-channel $\mathrm{CH}_{4}$ concentrations and fluxes. However, the cross-channel variability of $\mathrm{CH}_{4}$ is not usually included in river studies because the mixing of the entire water column in streams and rivers is assumed. Studies dealing with the spatial distribution of $\mathrm{CH}_{4}$ in the sediments of rivers report higher $\mathrm{CH}_{4}$ concentration in pore water of nearshore and riparian habitats, while the hyporheic sediments in mid-channel have usually lower $\mathrm{CH}_{4}$ concentrations (Jones et al., 1995; Crawford et al., 2014). This pattern probably results from the different rate of water exchange between surface water and sediments, leading to oxygen depletion in the uppermost sediment layer of nearshore habitats (Malard et al., 2002), while the sediments on the central river bottom are oxygenated to a large depth due to rapid vertical hydrological exchange with the flowing water column (Fischer et al., 2005). Consequently, oxygen depletion together with high sedimentation rate and supply of allochthonous labile organic matter from the riparian vegetation creates suitable conditions for high methanogenic activity in nearshore sediments (Jones et al., 1995; Jones and Mulholland, 1998; Stanley et al., 2016). However, it should be noted that microbial activity in total (including aerobic and anaerobic bacterial metabolism) is highest in the central channel, only due to connectivity with the surface water, which supplies the organic matter into deeper sediment layers (Fischer et al., 2005).

Our previous study revealed a significant effect of weir impoundments on methane river dynamics (production, oxidation, emission, methanogenic pathways) compared to usual river reaches (Bednařík et al., 2017), but a study describing the cross-channel variability of $\mathrm{CH}_{4}$ in the sediments upstream of weirs is not known to us. Hence, the overall aim of this study was to get more detailed information about the spatial variability of $\mathrm{CH}_{4}$-related processes in a river impoundment. For this purpose, we examined i) $\mathrm{CH}_{4}$ production and oxidation rates of the sediments; ii) relationships between environmental variables; and iii) contribution of the methanogenic pathways to total $\mathrm{CH}_{4}$ production using stable carbon isotopes, all in a crosschannel profile and two different sediment depths of a small river impoundment in Central Europe.

\section{METHODS}

\section{Study site and sampling}

The study area was located upstream of a weir situated in the Morava River, Czech Republic (Fig. 1; 49 $35^{\prime} 12^{\prime}$ 'N, $\left.17^{\circ} 15^{\prime} 43^{\prime \prime} \mathrm{E}\right)$. The Morava River is a seventh-order river (according to Strahler, 1957) with a mean annual water discharge of $26.4 \mathrm{~m}^{3} \mathrm{~s}^{-1}$ in the area of our study site. The impoundment upstream of the weir is $40 \mathrm{~m}$ width at its widest point, and has a maximum depth of $3.2 \mathrm{~m}$. The backwater length is approximately $2.6 \mathrm{~km}$. Riparian vegetation is composed mainly by grasses, including reeds and willows. The river channel was without any aquatic macrophytes.

Sediment samples were collected along the crosssection profile of the impoundment (Fig. 2). Triplicates were taken by a piston corer from eight different distances from the bank line to the mid-channel $(0 \mathrm{~m}, 2 \mathrm{~m}, 4 \mathrm{~m}, 6$ $\mathrm{m}, 8 \mathrm{~m}, 10 \mathrm{~m}, 12 \mathrm{~m}, 14 \mathrm{~m}$ ) and from two sediment depths $(0-10 \mathrm{~cm}$ and $10-20 \mathrm{~cm})$ for each distance. Samples were collected during artificial reduction of the water level in July 2014 caused by weir manipulation, and allowing efficient and accurate sediment sampling when the sediments were shortly exposed to air.

\section{Incubation experiments}

Sediments intended for incubation experiments were sieved through a $1-\mathrm{mm}$ sieve to remove coarse detritus, stones or invertebrates, and stored at $4^{\circ} \mathrm{C}$ until subsequent analyses and laboratory experiments were carried out. Samples for granulometric analysis were dried and then sieved through a system of ten sieves of decreasing mesh sizes. All separate fractions of the sediment grain sizes were weighed, and grain median size was analyzed using the software Gradistat (ver. 8.0) (Blott and Pye, 2001). The $\mathrm{C}, \mathrm{N}$, and $\mathrm{H}$ content of the sediments was quantified on a CHNS-element analyzer (vario MICRO cube, Hanau, Germany) by the Analytical Chemical Laboratory of the University of Marburg, Germany. The dry weight of the sample was determined gravimetrically.

For determination of $\mathrm{CH}_{4}$ production potential and methanogenic pathways, approximately $30 \mathrm{~g}$ (wet weight) of the sediments were transferred into 60 -mL sterile serum bottles in triplicates, flushed with $\mathrm{N}_{2}$, closed with butyl 
rubber stoppers and incubated at $25^{\circ} \mathrm{C}$ in a dark room. At the start of the incubation (before flushing with $\mathrm{N}_{2}$ ), $5 \mathrm{~mL}$ of distilled autoclaved water was added into each bottle for sampling of the liquid phase. The liquid phase was sampled at the end of the incubation for analyses of concentration and $\delta^{13} \mathrm{C}$ of acetate. The gas headspace of half of the bottles was supplemented with $3 \% \mathrm{CH}_{3} \mathrm{~F}$ to specifically inhibit acetotrophic methanogenesis (Janssen and Frenzel, 1997). Gas samples $(200 \mu \mathrm{l})$ were taken repeatedly (twice a week) during the course of incubation (4-6 weeks) and analyzed for concentrations of $\mathrm{CH}_{4}, \mathrm{CO}_{2}$, and $\delta^{13} \mathrm{C}$ of $\mathrm{CH}_{4}$ and $\mathrm{CO}_{2}$. The $\mathrm{CH}_{4}$ concentration was analyzed by gas chromatography (GC) using a flame ionization detector (Shimadzu, Kyoto, Japan) and $\mathrm{CO}_{2}$ concentration was analyzed after conversion to $\mathrm{CH}_{4}$ with a methanizer (Ni-catalystat $350^{\circ} \mathrm{C}$, Chrompack, Middelburg, the Netherlands).

Twenty grams (wet weight) of sediment samples for determination of the $\mathrm{CH}_{4}$ oxidation potential were placed in sterile bottles $(250 \mathrm{~mL})$ in triplicates, closed by a cap with PTFE silicone septa with ambient air in the headspace and then supplemented with $\mathrm{CH}_{4}$ to give a final concentration of $10,000 \mathrm{ppm}$. The incubation was performed at $25^{\circ} \mathrm{C}$ in a dark room. The concentration of $\mathrm{CH}_{4}$ in the headspace of each bottle was measured at $0 \mathrm{~h}$ and then ten times over $190 \mathrm{~h}$. The $\mathrm{CH}_{4}$ production and oxidation potentials were calculated from the slope of $\mathrm{CH}_{4}$ concentration change over time.

\section{Isotopic analyses and calculations}

Isotope measurements of ${ }^{13} \mathrm{C} /{ }^{12} \mathrm{C}$ in gas samples were performed on a gas chromatograph combustion isotope ratio mass spectrometer (GC-C-IRMS) system (Thermo Fisher Scientific, Bremen, Germany). The principal operation has been described by Brand (Brand, 1996). Other details are given in Penger et al. (2012) and Blaser et al. (2013). Isotopic analysis and quantification of acetate were performed on a high pressure liquid chromatography (HPLC) system (Spectra System P1000, Thermo Fisher Scientific, San Jose, CA; Mistral, Spark, Emmen, The Netherlands) equipped with an ion-exclusion column (Aminex HPX-87-H, BioRad, München, Germany) and coupled to Finnigan LC IsoLink (Thermo Fisher Scientific, Bremen, Germany) as described by Krummen et al., 2004. Isotope ratios were detected on an IRMS (Finnigan MAT Deltaplus Advantage).

Isotopic calculations of fractionation factors and estimation of the approximate partition of hydrogenotrophic methanogenesis to total methanogenesis were calculated according to a previously published procedure (Conrad, 2005; Blaser and Conrad, 2016).

In principal, partition of hydrogenotrophic methanogenesis was calculated by the following mass balance equation:

$$
f_{m c}=\left(\delta_{C H_{4}}-\delta_{m a}\right) /\left(\delta_{m c}-\delta_{m a}\right)
$$

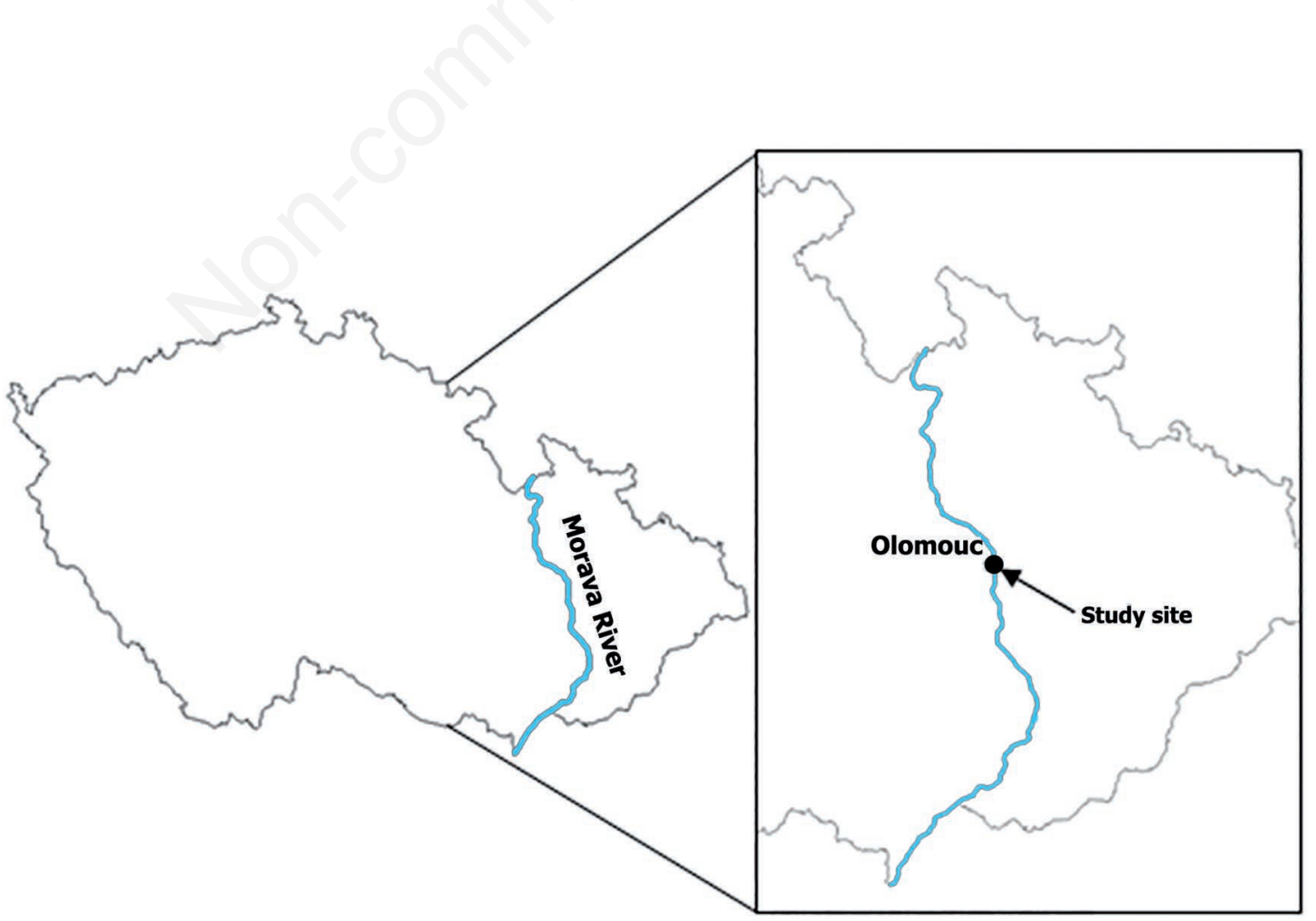

Fig. 1. Location of the Morava River in the Czech Republic and position of the study site in the river. 
where $f_{\mathrm{mc}}$ is the fraction of hydrogenotrophic methanogenesis; $\delta_{\mathrm{CH} 4}$ is the directly measured isotopic signature of the carbon in $\mathrm{CH}_{4} ; \delta_{\mathrm{mc}}$ is the carbon isotopic signature of $\mathrm{CH}_{4}$ solely produced from $\mathrm{CO}_{2}$ (directly measured from assays inhibited by methylfluoride) and $\delta_{\text {ma }}$ is the carbon isotopic signature of $\mathrm{CH}_{4}$ solely produced from acetate, the latter calculated from the following equation:

$\delta_{m a}=\left(1 / \alpha_{m a}\right)\left(\delta_{a c}+10^{3}-\alpha_{m a} 10^{3}\right)$

where $\alpha_{\text {ma }}$ is the fractionation factor for acetoclastic methanogenesis ( $\alpha_{\mathrm{ma}}=1.009$; Goevert and Conrad, 2009) and $\delta_{\mathrm{ac}}$ is the measured isotopic signal of acetate.

\section{Statistical analysis}

Data analyses were performed using the software STATISTICA 12 (StatSoft, 2013). The Mann-Whitney U test was used for examination of differences between surface and deeper sediment layers, as well as between individual distances from the bank. Spearman's correlation analysis was used to find the relationship between variables. The significance level of $\mathrm{P}<0.05$ was applied for all statistical analyses.

\section{RESULTS}

\section{Sediment characteristics}

The median grain size of sediments ranged from 0.3 to $9.8 \mathrm{~mm}$, and it was significantly smaller at the surface sediment layer $(0-10 \mathrm{~cm}$; mean $2.4 \pm 0.95 \mathrm{~mm})$ compared to deeper sediments $(10-20 \mathrm{~cm}$; mean $6.5 \pm 1.3 \mathrm{~mm})(\mathrm{P}<0.05)$. The carbon content ranged from 0.1 to $7.0 \%$ and it was significantly higher in the surface sediment layer (mean $2.5 \pm 0.6 \%$ ) compared to deeper sediments (mean $1.1 \pm 0.5 \%$ ) $(\mathrm{P}<0.05)$. Similarly, the nitrogen content ranged from 0.01 to $0.67 \%$ and was significantly higher in the surface sediment layer (mean $0.24 \pm 0.05 \%$ ) compared to deeper sediments (mean $0.11 \pm 0.04 \%)(\mathrm{P}<0.05)$. The $\mathrm{C} / \mathrm{N}$ ratio was almost the same in all samples and both sediment depths, with a mean of $10 \pm 0.1$ (Tab. 1).

\section{Methane production and oxidation by sediments}

Mean $\mathrm{CH}_{4}$ production potential ranged between 0 and $2.4 \mu \mathrm{mol} \mathrm{gDW}^{-1} \mathrm{~d}^{-1}$ (Fig. 3A). The methane production of nearshore sediments $(0-4 \mathrm{~m}$; mean $1.3 \pm 0.3 \mu \mathrm{mol}$ $\left.\mathrm{gDW}^{-1} \mathrm{~d}^{-1}\right)$ was significantly higher compared to the rest of the samples (6-14 m; mean $\left.0.2 \pm 0.1 \mu \mathrm{mol} \mathrm{gDW}^{-1} \mathrm{~d}^{-1}\right)$ $(\mathrm{P}<0.05)$. In total, the surface sediment layer $(0-10 \mathrm{~cm}$; mean $0.9 \pm 0.2 \mu \mathrm{mol} \mathrm{gDW}^{-1} \mathrm{~d}^{-1}$ ) had significantly higher $\mathrm{CH}_{4}$ production than the deeper layer $(10-20 \mathrm{~cm}$; mean $\left.0.3 \pm 0.2 \mu \mathrm{mol} \mathrm{gDW}^{-1} \mathrm{~d}^{-1}\right)(\mathrm{P}<0.05)$. Mean $\mathrm{CH}_{4}$ oxidation potential of sediments ranged from 0.5 to $13.3 \mu \mathrm{mol}$

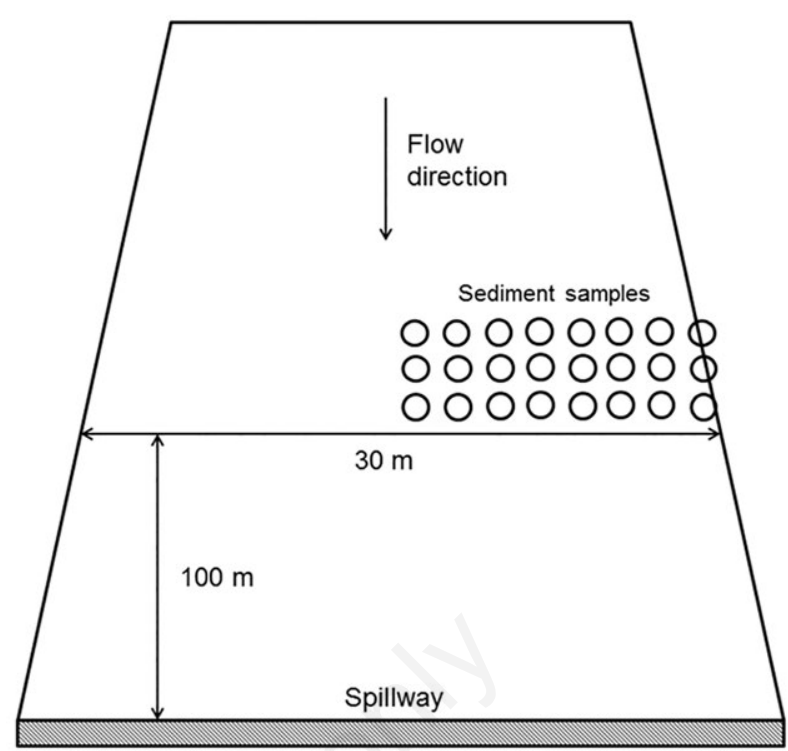

Fig. 2. The schematic of the sediment sampling in the crosschannel profile of a small river impoundment. Triplicates were taken from eight different distances from the bank line to the mid-channel (0 m, 2 m, 4 m, 6 m, 8 m, 10 m, 12 m, 14 m).
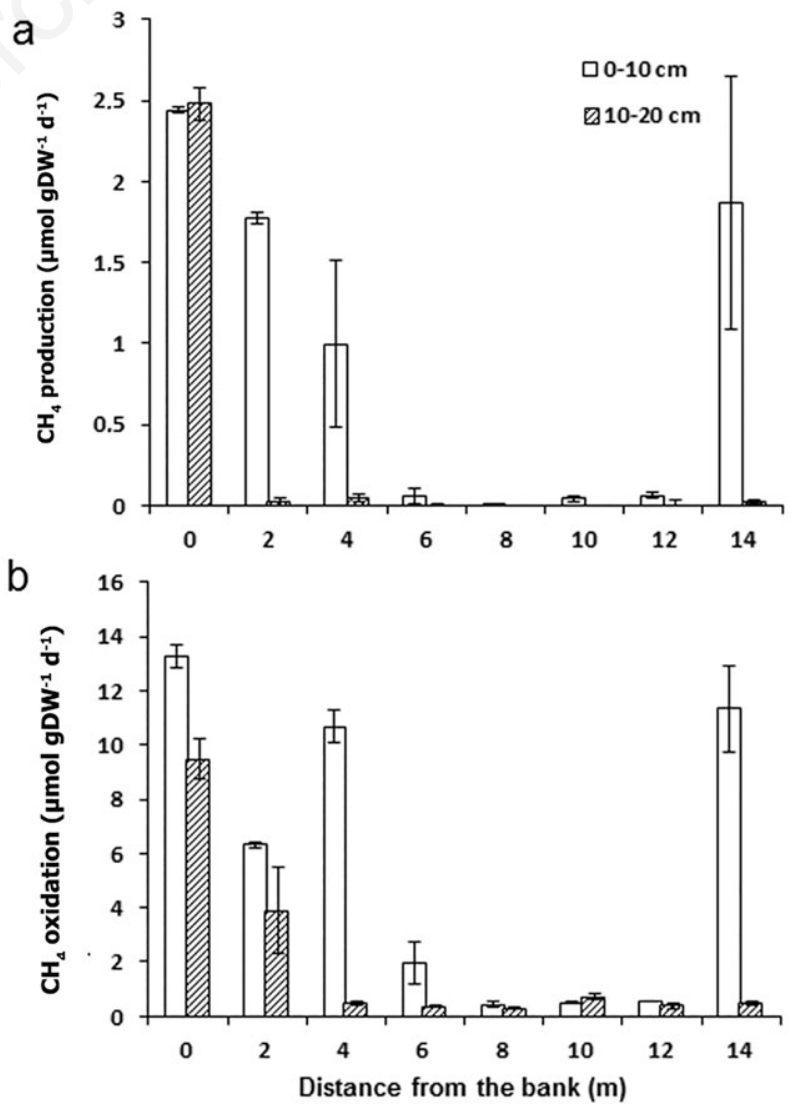

Fig. 3. The $\mathrm{CH}_{4}$ production (a) and oxidation (b) potentials of sediments (mean values $\pm \mathrm{SE}$ ). 
$\mathrm{gDW}^{-1} \mathrm{~d}^{-1}$ and showed the same spatial pattern as observed for the $\mathrm{CH}_{4}$ production potential (Fig. 3B). The nearshore sediments $\left(0-4 \mathrm{~m}\right.$; mean $7.4 \pm 1.1 \mu \mathrm{mol} \mathrm{gDW}^{-1}$ $\mathrm{d}^{-1}$ ) had higher $\mathrm{CH}_{4}$ oxidation potential compared to rest of the sampled sediments $(6-14 \mathrm{~m}$; mean $1.7 \pm 0.6 \mu \mathrm{mol}$ $\left.\mathrm{gDW}^{-1} \mathrm{~d}^{-1}\right)(\mathrm{P}<0.05)$. In addition, the surface sediment layer $\left(0-10 \mathrm{~cm}\right.$; mean 5.6 $\left.\pm 1.1 \mu \mathrm{mol} \mathrm{gDW}^{-1} \mathrm{~d}^{-1}\right)$ reached significantly higher $\mathrm{CH}_{4}$ oxidation than deeper sediments $\left(10-20 \mathrm{~cm}\right.$; mean 2.0 $\left.\pm 0.7 \mu \mathrm{mol} \mathrm{gDW}^{-1} \mathrm{~d}^{-1}\right)(\mathrm{P}<0.05)$.

Samples with the highest $\mathrm{CH}_{4}$ production rates were characterized by immediate and linear $\mathrm{CH}_{4}$ concentration increase during the sediment incubation (Fig. 4A), while the less productive samples were characterized by a lag phase, which takes 10-13 days from the start of the incubation, followed by linear or exponential $\mathrm{CH}_{4}$ concentration increase (Fig. 4B). The $\mathrm{CH}_{4}$ concentration in the headspace of the vials incubated for determination of the $\mathrm{CH}_{4}$ oxidation potential started to decrease after $7 \mathrm{~h}$ and continued to decrease linearly over the remaining time of the incubation (Fig. 5). The sediment $\mathrm{CH}_{4}$ oxidation and production potentials were strongly positively correlated with the carbon content as well as with the nitrogen content in sediments, while it was negatively correlated with the median grain size (Tab. 2).

\section{Methanogenic pathways}

The mean $\delta^{13} \mathrm{C}$ of organic matter in sediments was $-27.9 \pm 0.4 \%$ VPDB $(\mathrm{n}=48)$ (Tab. 1). The $\delta^{13} \mathrm{C}$ of acetate accumulated in inhibited samples (without acetoclastic methanogenesis) was on average very comparable with
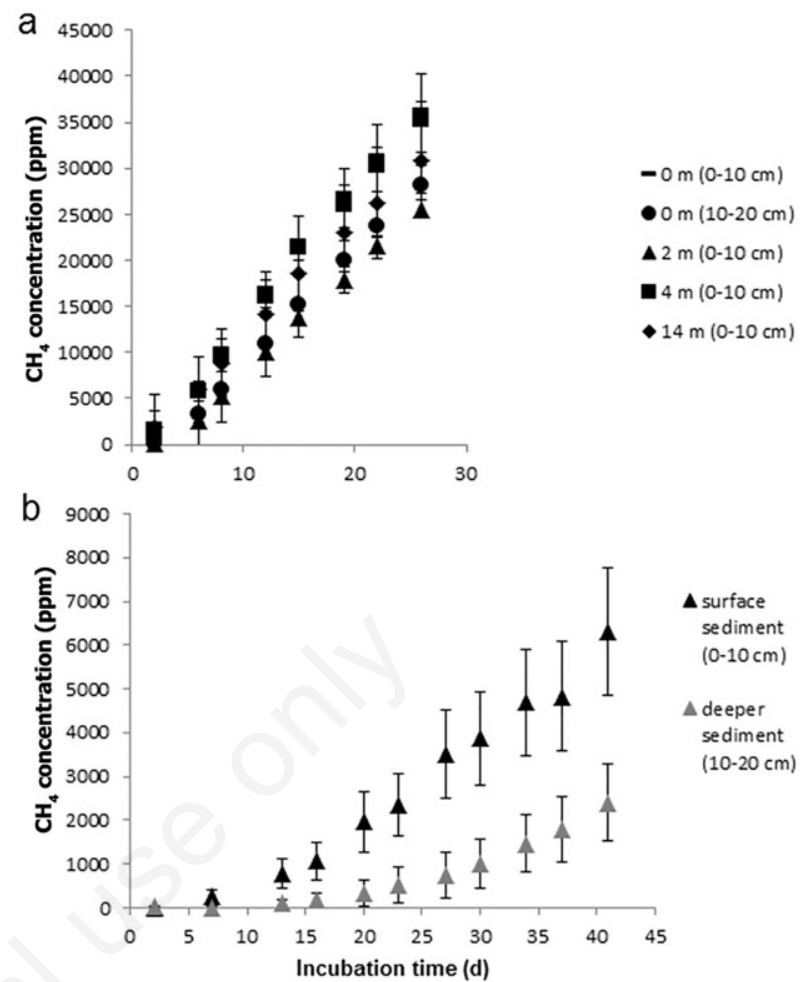

Fig. 4. Dynamics of $\mathrm{CH} 4$ formation during the incubation of (a) the most productive sediment samples (mean values $\pm \mathrm{SE}$ ), and (b) remaining (i.e., less productive samples characterized by a lag phase lasting more than one week after the start of the incubation) surface (6-12 m; black triangles) and deeper (2-14 $\mathrm{m}$; gray triangles) sediment samples in anoxic conditions (mean values $\pm \mathrm{SE})$.

Tab. 1. Measured characteristics of the sediment samples at two different depths (mean values \pm SE, $n=3$ ).

\begin{tabular}{|c|c|c|c|c|c|}
\hline Distance from the bank (m) & $\begin{array}{l}\text { Median grain } \\
\text { size }(\mathrm{mm})\end{array}$ & $\begin{array}{c}\text { Carbon content } \\
\qquad(\%)\end{array}$ & $\begin{array}{c}\text { Nitrogen content } \\
(\%)\end{array}$ & $\mathrm{C} / \mathrm{N}$ ratio & $\begin{array}{c}\delta^{13} \mathrm{C} \text { of organic } \\
\text { matter }\end{array}$ \\
\hline \multicolumn{6}{|c|}{$0-10 \mathrm{~cm}$} \\
\hline 0 & 0.47 & $6.7 \pm 0.1$ & $0.63 \pm 0.01$ & $10.6 \pm 0.1$ & $-28.3 \pm 0.1$ \\
\hline 2 & 0.78 & $5.7 \pm 0.1$ & $0.53 \pm 0.00$ & $10.6 \pm 0.1$ & $-29.3 \pm 1.4$ \\
\hline 4 & 7.70 & $2.4 \pm 1.3$ & $0.23 \pm 0.12$ & $10.2 \pm 0.2$ & $-28.1 \pm 0.1$ \\
\hline 6 & 5.18 & $0.4 \pm 0.1$ & $0.04 \pm 0.01$ & $10.1 \pm 0.2$ & $-27.2 \pm 0.1$ \\
\hline 8 & 0.79 & $0.2 \pm 0.0$ & $0.02 \pm 0.00$ & $10.1 \pm 0.3$ & $-27.1 \pm 0.1$ \\
\hline 10 & 0.78 & $0.3 \pm 0.1$ & $0.03 \pm 0.00$ & $9.9 \pm 0.1$ & $-27.4 \pm 0.1$ \\
\hline 12 & 3.08 & $0.3 \pm 0.0$ & $0.03 \pm 0.00$ & $9.8 \pm 0.1$ & $-27.2 \pm 0.2$ \\
\hline 14 & 0.68 & $4.0 \pm 1.6$ & $0.39 \pm 0.16$ & $10.1 \pm 0.1$ & $-28.1 \pm 0.1$ \\
\hline \multicolumn{6}{|c|}{$10-20 \mathrm{~cm}$} \\
\hline 0 & 0.26 & $6.9 \pm 0.1$ & $0.66 \pm 0.00$ & $10.4 \pm 0.0$ & $-27.9 \pm 0.1$ \\
\hline 2 & 2.45 & $0.4 \pm 0.1$ & $0.04 \pm 0.01$ & $10.0 \pm 0.1$ & $-27.4 \pm 0.2$ \\
\hline 4 & 9.75 & $0.4 \pm 0.1$ & $0.04 \pm 0.01$ & $10.3 \pm 0.4$ & $-27.3 \pm 0.0$ \\
\hline 6 & 9.36 & $0.2 \pm 0.1$ & $0.02 \pm 0.00$ & $9.6 \pm 0.2$ & $-26.7 \pm 0.1$ \\
\hline 8 & 4.46 & $0.2 \pm 0.0$ & $0.02 \pm 0.00$ & $10.0 \pm 0.1$ & $-26.8 \pm 0.1$ \\
\hline 10 & 7.93 & $0.1 \pm 0.0$ & $0.01 \pm 0.00$ & $8.9 \pm 0.2$ & $-26.6 \pm 0.3$ \\
\hline 12 & 9.21 & $0.3 \pm 0.2$ & $0.03 \pm 0.01$ & $9.8 \pm 0.3$ & $-27.2 \pm 0.3$ \\
\hline 14 & 8.86 & $0.2 \pm 0.0$ & $0.02 \pm 0.00$ & $10.0 \pm 0.2$ & $-27.1 \pm 0.1$ \\
\hline
\end{tabular}



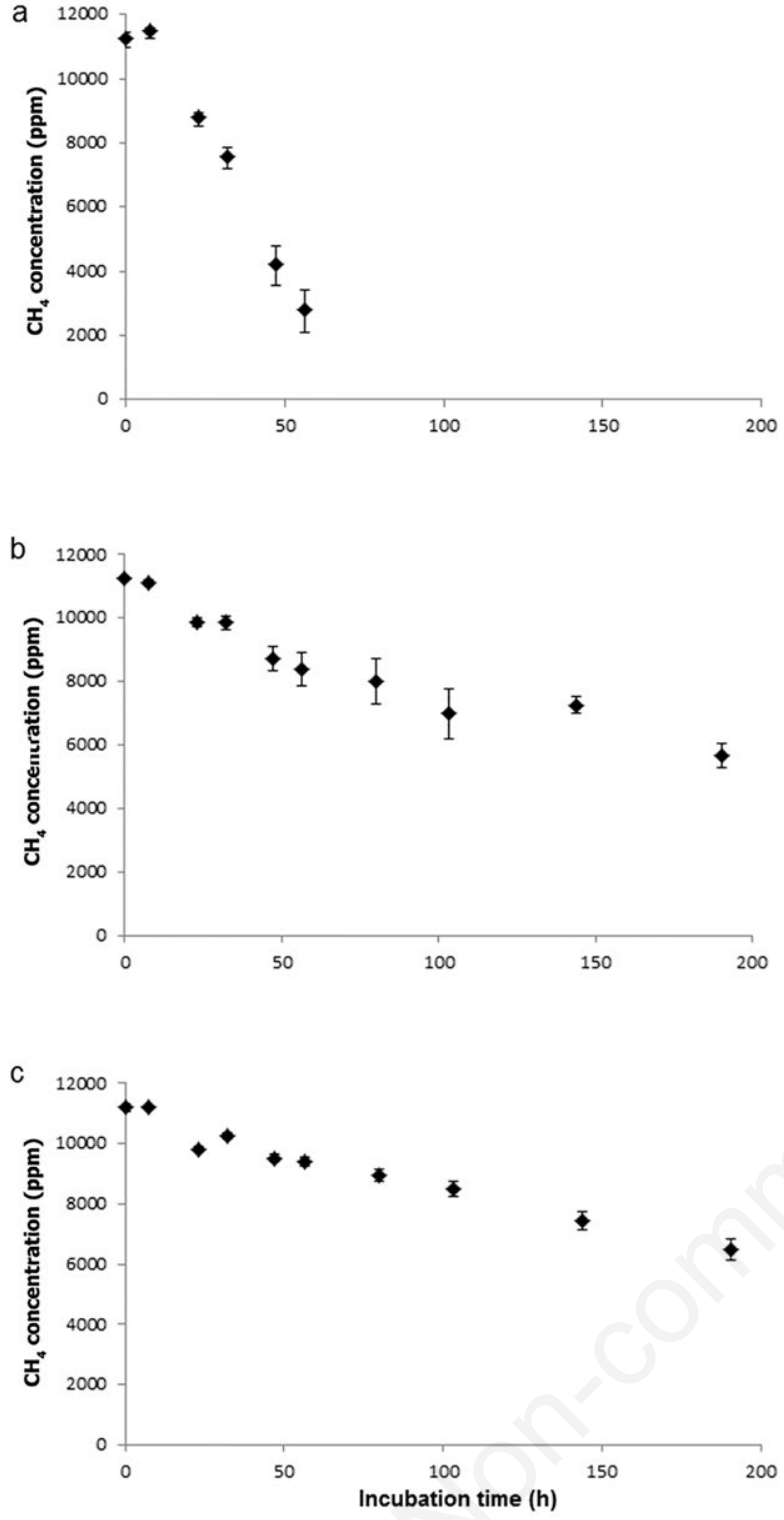

Fig. 5. Methane concentration decrease during the incubation of (a) the most active sediment samples ( $0 \mathrm{~m}, 2 \mathrm{~m}, 4 \mathrm{~m}, 14 \mathrm{~m})$, (b) remaining surface $(0-10 \mathrm{~cm})$ sediments $(6-12 \mathrm{~m})$, and $(\mathrm{c})$ remaining deeper $(10-20 \mathrm{~cm})$ sediments $(6-12 \mathrm{~m})$ in oxic conditions (mean values $\pm \mathrm{SE}$ ).
${ }^{13} \mathrm{C}$ of the organic matter with mean $-26 \pm 1.2 \%$ VPDB $(n=25)$. Acetate did not accumulate in uninhibited samples. The stable carbon isotopic composition of $\mathrm{CH}_{4}$ $\left(\delta^{13} \mathrm{C}-\mathrm{CH}_{4}\right)$ produced at the end of the uninhibited incubation was on average $-69.0 \pm 1.6 \%$ VPDB.

The contribution of hydrogenotrophic methanogenesis $\left(\mathrm{f}_{\mathrm{mc}}\right)$ to $\mathrm{CH}_{4}$ production was stable during the whole incubation time and ranged from 41 to $75 \%$ for individual samples (Fig. 6). The $\mathrm{CH}_{4}$ production was predominated by the $\mathrm{H}_{2} / \mathrm{CO}_{2}$-dependent methanogenic pathway in the surface sediment layer $(0-10 \mathrm{~cm})$ with mean $\mathrm{f}_{\mathrm{mc}}=56 \pm 0.02 \%$ at the end of the incubation (Fig. 6A). However, the contribution of acetoclastic and hydrogenotrophic methanogenesis to the total $\mathrm{CH}_{4}$

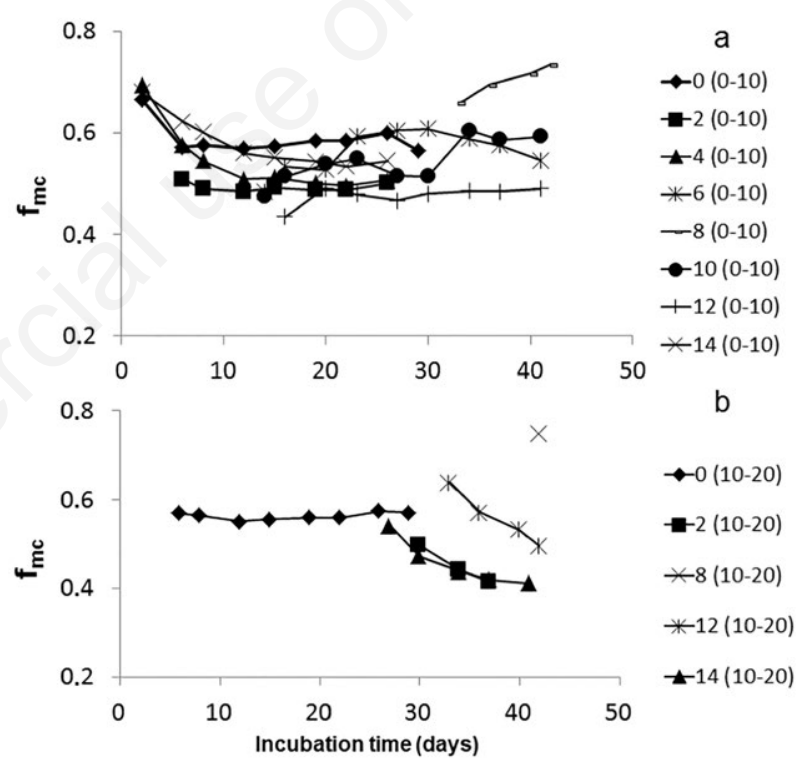

Fig. 6. The contribution of hydrogenotrophic methanogenesis ( $\left.f_{m c}\right)$ to total $\mathrm{CH}_{4}$ production in the samples of (a) the surface sediments $(0-10 \mathrm{~cm})$ and $(\mathrm{b})$ the deeper sediment layers $(10-20$ $\mathrm{cm})$. The missing time points are given by insufficient $\mathrm{CH}_{4}$ production rate for stable carbon isotopes measurement of the incubated sample.

Tab. 2. Values of the correlation coefficients (r) expressing the relationship between the examined variables. All correlations shown are significant at $\mathrm{P}<0.05$.

\begin{tabular}{lccccc} 
Variable & MPP & MOP & Carbon content & Nitrogen content & Median grain size \\
MPP & 1 & & & \\
\hline MOP & 0.67 & 1 & 1 & & \\
\hline Carbon content & 0.94 & 0.68 & 0.99 & 1 & \\
\hline Nitrogen content & 0.94 & 0.70 & -0.62 & -0.63 & 1
\end{tabular}

$\mathrm{MPP}, \mathrm{CH}_{4}$ production potential; $\mathrm{MOP}, \mathrm{CH}_{4}$ oxidation potential. 
production in the deeper sediment layer $(10-20 \mathrm{~cm})$ was balanced with mean $\mathrm{f}_{\mathrm{mc}}=51 \pm 0.05 \%$ and prevalence of $\mathrm{CH}_{4}$ production from acetate at the end of incubation of the three samples ( $2 \mathrm{~m}, 12 \mathrm{~m}, 14 \mathrm{~m}$; Fig. 6B).

\section{DISCUSSION}

\section{Spatial changes in $\mathrm{CH}_{4}$ production and oxidation}

In this study, we observed the highest methanogenic potential to be in the surface sediment layer $(0-10 \mathrm{~cm})$ at the distance of 0-4 $\mathrm{m}$ from the banks. A similar pattern regarding the active littoral sediments has been previously reported for lakes as well as rivers and it is mostly given by hydrological isolation and increased sedimentation rate in the nearshore habitats (Fischer et al., 2005; Murase et al., 2005). Moreover, littoral vegetation not only reduces the flow velocity, but can also serve as an additional source of organic matter (Sanders et al., 2007; Stanley et al., 2016). We expected more homogenous sediment parameters in cross-channel profiles due to the overall decrease of the flow velocity upstream of the weir. However, fine grain size and higher organic carbon content in the nearshore sediments observed in our study indicate a substantially increased sedimentation rate in this habitat. Nevertheless, after the nearshore sediments (0-4 m), we observed high potential $\mathrm{CH}_{4}$ formation and oxidation rates in the mid-channel surface sediments (14 $\mathrm{m})$. The best possible explanation is the accumulation of the fresh sediments in mid-channel due to channel morphology, as the mid-channel habitat is the deepest site in the cross-channel profile. In addition, the sediment characteristics (grain median size, carbon and nitrogen content) of the mid-channel samples were very similar to those from the nearshore habitat.

The methanogenic and methanotrophic potentials of the surface sediment layer $(0-10 \mathrm{~cm})$ were higher compared to the deeper sediment layer $(10-20 \mathrm{~cm})$. Generally, one would expect that better conditions for methanogens might occur in the deeper sediments, where the penetration of dissolved oxygen from the overlaying river water is lower and alternative electron acceptors such as dissolved $\mathrm{Fe}^{2+}, \mathrm{NO}_{3}{ }^{-}, \mathrm{SO}_{4}{ }^{2-}$ are depleted (Zehnder and Stumm, 1988). However, the results of our study suggested that availability of substrate for methanogens is the main factor driving the rate of $\mathrm{CH}_{4}$ production, since a strong positive correlation between $\mathrm{CH}_{4}$ production potential and organic carbon content exists $(\mathrm{r}=0.94)$. High $\mathrm{CH}_{4}$ production in the surface sediment layer is not unexpected and has previously been reported in lake sediments (Conrad et al., 2009), river sediments (Mach et al., 2015) and sediments of impounded river zones (Wilkinson et al., 2015).

Another possible factor influencing the $\mathrm{CH}_{4}$ production rate is likely the $\mathrm{C} / \mathrm{N}$ ratio, which is frequently mentioned in studies dealing with the methanogenic activity of sediments. It was found that the total nitrogen content best reflects easily degradable organic substrates available for the methanogens and it is highly correlated with maximum methanogenesis (Yao et al., 1999; Gebert et al., 2006). Duc et al. (2010) recognized that the highest potential $\mathrm{CH}_{4}$ formation rate is in the sediments with lower $\mathrm{C} / \mathrm{N}$ ratios $(<10)$, while the sediments with higher $\mathrm{C} / \mathrm{N}$ ratios $(\sim 20)$ are characterized by lower $\mathrm{CH}_{4}$ formation rates despite the high organic carbon content, which is likely associated with the lability of organic matter. In our study, we observed a similar $\mathrm{C} / \mathrm{N}$ ratio $(\sim 10$; Tab. 1) across all sediment samples in this study. It may indicate the same source of organic material within all samples, and also confirms that the high variability of methanogenic activity was not caused by the degradability of organic substrates in the examined sediments, but rather by the total amount and the availability of organic substrates for the methanogens.

Despite the higher $\mathrm{CH}_{4}$ oxidation potential compared to the $\mathrm{CH}_{4}$ production potential of all incubated sediment samples (Fig. 3), sediments represent a source of $\mathrm{CH}_{4}$ into the surface water and the atmosphere. As suggested by Bednařík et al., 2017, increased $\mathrm{CH}_{4}$ concentrations were observed in surface water, together with high contribution of ebullition to the total $\mathrm{CH}_{4}$ emission upstream of the weirs. The discrepancy between $\mathrm{CH}_{4}$ production potential and $\mathrm{CH}_{4}$ oxidation potential in sediments is given by substrate addition $\left(\mathrm{CH}_{4}\right)$ during incubation experiments. Hence, this serves mainly for a comparison of the microbial activity between individual samples and not for calculation of the net $\mathrm{CH}_{4}$ flux from the sediments. It would be necessary to measure in situ $\mathrm{CH}_{4}$ benthic fluxes from the sediments to the surface water using the benthic chamber method in order to determine the net contribution of the sediments to the surface water $\mathrm{CH}_{4}$ (Sansone et al., 1998; Bednařík et al., 2015).

We assume that short exposure (several hours) of sediments to air during the reduction of water level upstream of the weir (see Methods, above) had no significant effect on the results presented in this study. Several studies have revealed that methanogenic archaea can survive in aerated and dry soils even in numbers similar to the original state (Mayer and Conrad, 1990; Fetzer et al., 1993). Hernández et al. (2019) have recently shown that even after sediment desiccation and rewetting, rates and pathways of $\mathrm{CH}_{4}$ production remain similar despite changes in the microbial community composition.

\section{Methanogenic pathways}

Generally, $\mathrm{CH}_{4}$ production consists of three distinct phases: i) the first is the lag phase (also reduction phase), during which most of the inorganic electron acceptors in 
the sediments, such as nitrate, sulfate or ferric iron, are depleted and only $\mathrm{CO}_{2}$ is produced; ii) the methanogenic phase, characterized by strong $\mathrm{CH}_{4}$ formation which maximally depends on the sediment characteristics; iii) in the third phase (the steady state phase), $\mathrm{CH}_{4}$ production decreases to the stable and long-term level (Yao et al., 1999; Gebert et al., 2006). We observed no lag phase for the most active sediment samples where the $\mathrm{CH}_{4}$ production was rapid. An absence of lag phase at the start of the $\mathrm{CH}_{4}$ production could be explained either by i) overlap of the reduction and methanogenic phases (i.e., $\mathrm{CH}_{4}$ production started at a relatively high redox potential before the full depletion of inorganic electron acceptors; Yao et al., 1999); or ii) inorganic electron acceptors were depleted already before the start of the incubation, because the sediments were fully anoxic (Conrad et al., 2009). However, concentration of the alternative electron acceptors was not measured in our study. Nevertheless, it has been previously shown that the total $\mathrm{CH}_{4}$ production is strongly negatively correlated with the duration of the lag phase (Yao et al., 1999), which can be completely confirmed by the results of our study.

Despite different rates of $\mathrm{CH}_{4}$ production, the resulting contribution of individual methanogenic pathways was very similar for all examined samples of surface sediments $(0-10 \mathrm{~cm})$. The predominant pathway of $\mathrm{CH}_{4}$ production in surface sediments was the consistent reduction of $\mathrm{H}_{2}$ and $\mathrm{CO}_{2}$ (hydrogenotrophic methanogenesis) throughout the examined samples, which is in agreement with our previous results from sites upstream of the weirs, while the river sections are characterized rather by the predominant acetoclastic methanogenesis (Avery and Martens, 1999; Mach et al., 2015; Bednař́k et al., 2017). The stoichiometrically given portion of individual methanogenic pathways $(66 \%$ from acetate and $33 \%$ from $\mathrm{H}_{2} / \mathrm{CO}_{2}$; Conrad, 1999) usually fits well on rice field soils (Conrad et al., 2002; Fey et al., 2004), but it can considerably vary throughout the different freshwater ecosystems (Murase and Sugimoto, 2001; Galand et al., 2010; Conrad et al., 2011). Possible explanations for the deviations in this portion are described for instance in Conrad (1999) and Conrad et al. (2009). In the case of higher contribution of $\mathrm{CH}_{4}$ production from acetate, this can be easily explained by homoacetogenesis (reduction of $\mathrm{CO}_{2}$ with $\mathrm{H}_{2}$ via the acetyl-CoA) (Mach et al., 2015), while the higher contribution of the hydrogenotrophic pathway to total $\mathrm{CH}_{4}$ production can be given by several processes. Basically, we can exclude the not-steady-state conditions because the acetate did not accumulate in the uninhibited samples (without the addition of $\mathrm{CH}_{3} \mathrm{~F}$ ). Syntrophic acetate oxidation is exceptional in freshwater sediments and unlikely to explain the major part of $\mathrm{CH}_{4}$ production. The most probable explanation remains incomplete degradation of organic matter, i.e., an additional source of $\mathrm{H}_{2}$, which deflects the resulting contribution of methanogenic pathways, which has been previously observed for lake sediments (Conrad et al., 2009; Conrad et al., 2011).

It is worth noting that hydrogenotrophic methanogenesis was not prevalent in the deeper sediment layer $(10-20 \mathrm{~cm})$, where the contribution of the individual methanogenic pathways was equivalent and acetoclastic methanogenesis was prevalent at the end of the incubation experiments of three samples $(2 \mathrm{~m}, 12 \mathrm{~m}, 14 \mathrm{~m})$. The shift in the contribution of methanogenic pathways was probably not caused by the lability or availability of organic substrate, because of the similarity of these parameters between examined sediment layers (Tab.1). One would expect that the composition of the microbial community can be important for the determination of methanogenic pathways. However, Conrad et al. (2011) have shown that the composition of microbial methanogenic communities does not correspond with the resulting contribution of individual pathways of $\mathrm{CH}_{4}$ production. In spite of the molecular analysis of the methanogenic marker-gene $(m c r A)$, which revealed a significantly different methanogenic community for the top layer in contrast to deeper layers, the contribution of individual methanogenetic pathways was very similar throughout all examined samples in Mach et al. (2015). Similarly, Chaudhary et al. (2017) have found no relationship between the absolute numbers of the methanogenic community and the level of $\mathrm{CH}_{4}$ production. However, studies dealing with the varying contribution of methanogenic pathways in the vertical profile of freshwater sediments are very scarce and deserve to be considered in greater detail in further studies.

\section{CONCLUSIONS}

We found that the most productive sites in the impounded river zones are littoral sediments; as was previously reported for different freshwater habitats, including lakes and rivers. However, we also observed substantially high $\mathrm{CH}_{4}$ production in mid-channel sediments, which is likely due to channel morphology causing the accumulation of sediment in this habitat. Hence, the methanogenic and methanotrophic activity of sediments was associated with sites with the finest median grain size of sediments and were best correlated with carbon and nitrogen content. Our results show that it is necessary to consider the sampling location for better representation of particular water habitats. Sediment samples taken only in the littoral zones of water habitats can significantly misrepresent the further extrapolation of obtained results. Considering the substantial sediment $\mathrm{CH}_{4}$ production potential upstream of weirs, studies focusing on quantification of direct $\mathrm{CH}_{4}$ fluxes from sediments to surface water and conducted in situ are necessary. 


\section{ACKNOWLEDGMENTS}

We would like to thank Peter Claus for technical assistance and for HPLC-IRMS analysis. This study was financially supported by Palacký University grant IGA_PrF_2017_015.

\section{REFERENCES}

Anthony SE, Prahl FG, Peterson TD, 2012. Methane dynamics in the Willamette River, Oregon. Limnol. Oceanogr. 57:1517-1530.

Avery GB, Martens ChS, 1999. Controls on the stable carbon isotopic composition of biogenic methane produced in a tidal freshwater estaurine sediment. Geochim. Cosmochim. Ac. 63:1075-1082.

Barth JAC, Cronin AA, Dunlop J, Kalin RM, 2003. Influence of carbonates on the riverine carbon cycle in an anthropogenically dominated catchment basin: evidence from major elements and stable carbon isotopes in the Lagan River (N. Ireland). Chem. Geol. 200:203- 216.

Bastviken D, Cole JJ, Pace ML, Van de Bogert MC, 2008. Fates of methane from different lake habitats: Connecting wholelake budgets and $\mathrm{CH} 4$ emissions. J. Geophys. Res. 113:G02024. doi: s10.1029/2007JG000608.

Bastviken D, Tranvik LJ, Downing JA, Crill PM, Prast AE, 2011. Freshwater methane emissions offset the continental carbon sink. Science 331:50.

Bednařík A, Čáp L, Maier V, Rulík M, 2015. Contribution of methane benthic and atmospheric fluxes of an experimental area (Sitka Stream). Clean Soil Air Water 43:1136-1142.

Bednařík A, Blaser M, Matoušů A, Hekera P, Rulík M, 2017. Effect of weir impoundments on methane dynamics in a river. Sci. Total Environ. 584-585:164-174.

Blaser M, Dreisbach LK, Conrad R, 2013. Carbon isotope fractionation of 11 acetogenic strains grown on $\mathrm{H}_{2}$ and $\mathrm{CO}_{2}$. Appl. Environ. Microbiol. 79:1787-1794. doi: 10.1128/AEM. 03203-12.

Blaser M, Conrad R, 2016. Stable carbon isotope fractionation as tracer of carbon cycling in anoxic soil ecosystems. Curr. Opin. Biotech. 41:122-129. doi: 10.1016/j.copbio.2016.07.001.

Blott SJ, Pye K, 2001. Gradistat: A grain size distribution and statistics package for the analysis of unconsolidated sediments. Earth Surf. Proc. 26:1237-1248.

Bussmann I, 2005. Methane release through resuspension of littoral sediment. Biogeochemistry 74:283-302. doi: 10.1007/ s10533-004-2223-2.

Brand WA, 1996. High precision isotope ratio monitoring techniques in mass spectrometry. J. Mass Spectrom. 31:225235 .

Chaudhary PP, Rulík M, Blaser M, 2017. Is the methanogenic community reflecting the methane emissions of river sediments? - comparison of two study sites. Microbiologyopen 6:e00454. doi: 10.1002/mbo3.454.

Conrad R, 1999. Contribution of hydrogen to methane production and control of hydrogen concentrations in methanogenic soils and sediments. FEMS Microbiol. Ecol. 28:193-202.

Conrad R, 2005. Quantification of methanogenic pathways using stable carbon isotopic signatures: a review and a proposal. Org. Geochem. 36:739-752. doi: 10.1016/j.orggeochem. 2004.09.006

Conrad R, Klose M, Claus P, 2002. Pathway of $\mathrm{CH}_{4}$ formation in anoxic rice field soil and rice roots determined by ${ }^{13} \mathrm{C}$ stable isotope fractionation. Chemosphere 47:797-806. doi:10.1016/S0045-6535(02)00120-0

Conrad R, Claus P, Casper P, 2009. Characterization of stable isotope fractionation during methane production in the sediment of a eutrophic lake, Lake Dagow, Germany. Limnol. Oceanogr. 54:457-471. doi: 10.4319/lo.2009.54.2.0457.

Conrad R, Noll M, Claus P, Klose M, Bastos WR, Enrich-Prast A, 2011. Stable carbon isotope discrimination and microbiology of methane formation in tropical anoxic lake sediments. Biogeosciences 8:795-814. doi:10.5194/bg-8795-2011

Crawford JT, Stanley EH, Spawn SA, Finlay JC, Loken LC, Striegl RG, 2014. Ebullitive methane emissions from oxygenated wetland streams. Glob. Chang. Biol. 20:34083422. doi: $10.1111 / \mathrm{gcb} .12614$.

Deemer BR, Harrison JA, Li S, Beaulieu JJ, Delsontro T, Barros N, Bezerra-Neto JF, Powers SM, Dos Santos MA, Vonk JA, 2016. Greenhouse gas emissions from reservoir water surfaces: A new global synthesis. BioScience 66:949-964. doi: 10.1093/biosci/biw117

Duc NT, Crill P, Bastviken D, 2010. Implications of temperature and sediment characteristics on methane formation and oxidation in lake sediments. Biogeochemistry 100:185-196. doi: 10.1007/s10533-010-9415-8.

Fetzer S, Bak F, Conrad R, 1993. Sensitivity of methanogenic bacteria from paddy soil to oxygen and desiccation. FEMS Microbiol. Ecol. 12:107-115.

Fey A, Claus P, Conrad R, 2004. Temporal change of ${ }^{13} \mathrm{C}$-isotope signatures and methanogenic pathways in rice field soil incubated anoxically at different temperatures. Geochim. Cosmochim. Ac. 68:293-306. doi:10.1016/S0016-7037(03) 00426-5

Fischer H, Kloep F, Wilzcek S, Pusch MT, 2005. A river's liver - microbial processes within the hyporheic zone of a large lowland river. Biogeochemistry 76:349-371.

Galand PE, Yrjälä K, Conrad R, 2010. Stable carbon isotope fractionation during methanogenesis in three boreal peatland ecosystems. Biogeosciences 7:3893-3900. doi:10.5194/bg7-3893-2010

Gao Y, Wang B, Liu X, Wang Y, Zhang J, Jiang YX, Wang FS, (2013). Impacts of river impoundment on the riverine water chemistry composition and their response to chemical weathering rate. Front. Earth Sci. 7:351-360.

Gebert J, Köthe H, Gröngröft A, 2006. Prognosis of methane formation by river sediments. J. Soils Sediments 6:75-83. doi: $10.1065 /$ jss2006.04.153.

Goevert D, Conrad R, 2009. Effect of substrate concentration on carbon isotope fractionation during acetoclastic methanogenesis by Methanosarcina barkeri and $\mathrm{M}$. acetivorans and in rice field soil. Appl. Environ. Microbiol. 75:2605-2612. doi: 10.1128/AEM.02680-08

Hernández M, Klose M, Claus P, Bastviken D, Marotta H, Figueiredo V, Enrich-Prast A, Conrad R, 2019. Structure, function and resilience to desiccation of methanogenic microbial communities in temporarily inundated soils of the 
Amazon rainforest (Cunia Reserve, Rondonia). Environ. Microbiol. 21:1702-1717. doi: 10.1111/1462-2920.14535

Hofmann H, Federwisch L, Peeters F, 2010. Wave-induced release of methane: Littoral zones as a source of methane in lakes. Limnol. Oceanogr. 55:1990-2000. doi:10.4319/1o. 2010.55.5.1990

IPCC, 2013. Climate Change 2013: The physical science basis. Contribution of Working Group I to the Fifth Assessment Report of the Intergovernmental Panel on Climate Change. Cambridge University Press, Cambridge, United Kingdom and New York, NY, USA.

Janssen PH, Frenzel P, 1997. Inhibition of methanogenesis by methyl fluoride: Studies of pure and defined mixed cultures of anaerobic bacteria and archaea. Appl. Environ. Microbiol. 63:4552-4557.

Jones JB, Holmes RM, Fisher SG, Grimm NB, Greene DM, 1995. Methanogenesis in Arizona, USA dryland streams. Biogeochemistry 31:155-173.

Jones JB, Mulholland PJ, 1998. Influence of drainage basin topography and elevation on carbon dioxide and methane supersaturation of streamwater. Biogeochemistry 40:57-72.

Krummen M, Hilkert AW, Juchelka D, Duhr A, Schluter HJ, Pesch R, 2004. A new concept for isotope ratio monitoring liquid chromatography/mass spectrometry. Rapid Commun. Mass Spectrom. 18:2260-2266. doi: 10.1002/rcm.1620

Mach V, Blaser M, Claus P, Chaudhary PP, Rulik M, 2015. Methane production potentials, pathways, and communities of methanogens in vertical sediment profiles of river Sitka. Front. Microbiol. 6:506. doi: 10.3389/fmicb.2015.00506

Maeck A, DelSontro T, McGinnis DF, Fischer H, Flury S, Schmidt M, Fietzek P, Lorke A, 2013. Sediment trapping by dams creates methane emission hot spots. Environ. Sci. Technol. 47:8130-8137. doi: 10.1021/es4003907.

Malard F, Tockner K, Dole-Olivier MJ, Ward JV, 2002. A landscape perspective of surface-subsurface hydrological exchanges in river corridors. Freshwater Biol. 47:621-640. doi: 10.1046/j.1365-2427.2002.00906.x.

Mayer HP, Conrad R. 1990, Factors influencing the population of methanogenic bacteria and the initiation of methane production upon flooding of paddy soil. FEMS Microbiol. Ecol. 73:103-112.

Murase J, Sugimuto A, 2001. Spatial distribution of methane in the Lake Biwa sediments and its carbon isotopic compositions. Geochem. J. 35:257-263. doi:10.2343/ geochemj.35.257.

Murase J, Sakai Y, Kametani A, Sugimoto A, 2005. Dynamics of methane in mesotrophic Lake Biwa, Japan. Ecol. Res. 20:377-385. doi:10.1007/s11284-005-0053-x.

Musenze RS, Grinham A, Werner U, Gale D, Sturm K, Udy J and Yuan Z, 2014. Assessing the spatial and temporal variability of diffusive methane and nitrous oxide emissions from subtropical freshwater reservoirs. Environ. Sci. Technol. 48:14499-14507. doi:10.1021/es505324h.

Ogbeibu AE, Oribhabor BJ, 2002. Ecological impact of river impoundment using benthic macro-invertebrates as indicators. Water Res. 36:2427-2436. doi: 10.1016/S00431354(01)00489-4.

Penger J, Conrad R, Blaser M, 2012. Stable carbon isotope fractionation by methylotrophic methanogenic archaea. Appl. Environ. Microbiol. 78:7596-7602. doi: 10.1128/ AEM.01773-12.

Richey JE, Devol AH, Wofsy SC, Victoria R, Riberio MNG, 1988. Biogenic gases and the oxidation and reduction of carbon in Amazon River and floodplain waters. Limnol. Oceanogr. 33:551-561.

Sanders IA, Heppell CM, Cotton JA, Wharton G, Hildrew AG, Flowers EJ, Trimmer M, 2007. Emission of methane from chalk streams has potential implications for agricultural practices. Freshwater Biol. 52:1176-1186. doi:10.1111/j. 1365-2427.2007.01745.x.

Sansone FJ, Rust TM, Smith SV, 1998. Methane distribution and cycling in Tomales bay, California. Estuaries 21:66-77.

Sawakuchi HO, Bastviken D, Sawakuchi AO, Krusche AV, Ballester MVR, Richey JE, 2014. Methane emissions from Amazonian Rivers and their contribution to the global methane budget. Glob. Change Biol. 20:2829-2840. doi: 10.1111/gcb.12646

Scavino AF, Ji Y, Pump J, Klose M, Claus P, Conrad R, 2013. Structure and function of the methanogenic microbial communities in Uruguayan soils shifted between pasture and irrigated rice fields. Environ. Microbiol. 15:2588-2602. doi:10.1111/1462-2920.12161

Stanley EH, Casson NJ, Christel ST, Crawford JT, Loken LC, Oliver SK, 2016. The ecology of methane in streams and rivers: patterns, controls, and global significance. Ecol. Monogr. 86:146-171 doi: 10.1890/15-1027.1.

Strahler A, 1957. Quantitative analysis of watershed geomorphology. Trans. Am. Geophys. Union. 38:913-920.

StatSoft Inc., 2013. STATISTICA, data analysis software system, ver. 12. Available from: www.statsoft.com

Wilkinson J, Maeck A, Alshboul Z, Lorke A, 2015. Continuous seasonal river ebullition measurements linked to sediment methane formation. Environ. Sci. Technol. 49:13121-13129 doi: 10.1021/acs.est.5b01525.

Yang M, Geng X, Grace J, Lu C, Zhu Y, Zhou Y, Lei G., 2014. Spatial and seasonal CH4 flux in the littoral zone of Miyun reservoir near Beijing: The effects of water level and its fluctuation. PLoS One 9:e94275. doi:10.1371/journal. pone.0094275.

Yao H, Conrad R, Wassmann R, Neue HU, 1999. Effect of soil characteristics on sequential reduction and methane production in sixteen rice paddy soils from China, the Philippines, and Italy. Biogeochemistry 47:269-295.

Zehnder AJB, Stumm W, 1988. Geochemistry and biogeochemistry of anaerobic habitats, p. 1-38. In: A.J.B. Zehnder (ed.), Biology of anaerobic microorganisms. Wiley, New York

Zinder SH, 1993. Physiological ecology of methanogens, p. 128206. In: J.FG. Ferry (ed.), Methanogenesis: Ecology, physiology, biochemistry and genetics. Springer, Boston. 